\title{
Salvific Dissolution: The Mystery of the Betrayal between the New Testament and the Gospel of Judas
}

\author{
JONATHAN CAHANA \\ Aarhus University, Jens Chr. Skous Vej 3, Building 1453, Room 427, 8000 Aarhus C, \\ Denmark.Email:joca@cas.au.dk
}

\begin{abstract}
The recently discovered Gospel of Judas has created much controversy among scholars. While it is clear that Judas is liable for Jesus' crucifixion in this text, it is much debated whether his actions should be understood positively or negatively. This article suggests that focusing on how the Gospel of Judas evaluates the salvific meaning of Jesus' crucifixion alongside the New Testament gospels and other early Christian writings may provide a key for solving this problem. In this way, the Gospel of Judas can be seen as a rare attempt to unravel what Irenaeus aptly termed 'the mystery of the betrayal'.
\end{abstract}

Keywords: crucifixion, Gnosticism, Jesus, Judas Iscariot, Gospel of Judas, New Testament gospels

\section{Introduction}

... And they say Judas the betrayer had meticulous knowledge of these things, and since only he among all the other [disciples] knew the truth, he accomplished the mystery of the betrayal: through him all things, both earthly and heavenly, were dissolved, they say. And they adduce a work of fiction to this effect, calling it 'The Gospel of Judas'.

For a short while after the Gospel of Judas from Codex Tchacos was published in 2006, it seemed as if Irenaeus' testimony was confirmed. ${ }^{2}$ There was

1 Irenaeus, Against Heresies 1.31.1, my translation. For the text, see A. Rousseau and L. Doutreleau, eds., Irénée de Lyon - Contre les hérésies, livre I, vol. II (Paris: Éditions du Cerf, 1979) 386.

2 R. Kasser, M. Meyer and G. Wurst, eds., The Gospel of Judas from Codex Tchacos (Washington: National Geographic, 2006). The critical edition was published in 2007: R. Kasser, G. Wurst, M. Meyer and F. Gaudard, eds., The Gospel of Judas, together with the Letter from Peter to Philip, James, and a Book of Allogenes from Codex Tchacos: Critical Edition (Washington: National Geographic, 2007). For additional fragments that resurfaced later, see H. Krosney, M. 
indeed a gnostic Gospel of Judas in which Judas excelled all other apostles in knowledge and brought about salvation by his betrayal of Jesus. Actually, it was not just an issue of excelling the other disciples; as in proto-orthodox Christianity, in the new gospel Judas and the disciples were understood to be opposed, only this time Judas was on the right side. Not long after the initial publication of the Gospel of Judas, however, this interpretation, presented by the National Geographic team who edited the manuscript, was challenged by many scholars. ${ }^{3}$ It was argued that the 'positive Judas' reading of the text could only be sustained through problematic, or downright mistaken, readings of the Coptic. For instance, at 44.20, Jesus calls Judas a 'demon' ( $\triangle$ dimon; the original editors first translated this as 'spirit', arguing that it underlines Judas' true spiritual nature); ${ }^{4}$ at 46.24 , Jesus makes it clear to Judas that he will not ascend to the holy kingdom (the original editors reconstructed and translated the exact opposite); ${ }^{5}$ and at 46.18, Judas complains to Jesus that he has separated him apart from

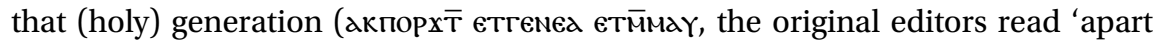
for'). ${ }^{6}$ Moreover, when Jesus tells Judas that he will excel the evil disciples who sacrifice to Saklas (56.18), the original editors understood Jesus' words as implying that Judas will be better than the other disciples, while the new reading argued - quite logically - that if the disciples are evil, Judas could only 'excel' them ( $\overline{\mathrm{P}}$ 2oүo €-, literally 'do more than') by becoming more evil, and would thus be the most evil character in his own gospel. ${ }^{7}$ On this interpretation then, Judas and the disciples are not opposed but simply vary in their degree of iniquity - Judas clearly the leader of the group. If that is so, what was the point of the gospel? Among others, April DeConick argued that the gospel was a gnostic parody on the sacrificial theology of the proto-orthodox church. ${ }^{8}$ According to this interpretation, its message

Meyer,and G. Wurst, 'Preliminary Report on New Fragments of Codex Tchacos', Early Christianity 1 (2010) 282-94.

3 E.g. A. D. DeConick, 'The Mystery of Betrayal: What Does the Gospel of Judas Really Say?', The Gospel of Judas in Context (ed. M. Scopello; Leiden: Brill, 2008) 239-64 and L. Painchaud, 'Polemical Aspects of the Gospel of Judas', Gospel of Judas in Context, 171-86.

4 Kasser et al., Gospel of Judas, 31. The critical edition opted for the more neutral 'daimon': Kasser et al., Gospel of Judas: Critical Edition, 207.

5 Kasser et al., Gospel of Judas, 33. Again, this has been revised in the critical edition: Kasser

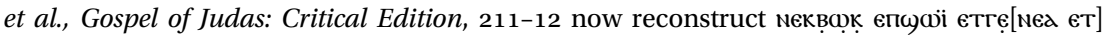
оүадв ('you will not ascend on high to the holy [generation]').

6 Kasser et al., Gospel of Judas, 32. This translation was retained in the critical edition, but a note indicating the alternative reading was added: Kasser et al., Gospel of Judas: Critical Edition, 211.

7 On this point, see DeConick, 'The Mystery', 245-6; and Painchaud, 'Polemical Aspects', 183-4.

8 DeConick, 'The Mystery', esp. 261-4; A. D. DeConick, 'Apostles as Archons: The Fight for Authority and the Emergence of Gnosticism in the Tchacos Codex and Other Early Christian Literature', The Codex Judas Papers (ed. A. D. DeConick; Brill: Leiden, 2009) 
can be summarised by the following: 'if indeed the death and sacrifice of Jesus are the salvific events in your belief, you proto-orthodox Christians should admire rather than curse - Judas, for without him it would never have happened; thus, here is your gospel and here is your hero'.

I have used a very broad brush to paint the differences between the disparate positions on this enigmatic gospel, and it must be admitted that ever since its original publication and subsequent criticisms, the lines separating these positions have become less sharply defined. While it is clear that the pendulum lies currently within the 'evil Judas' camp, the most recent publications on this gospel strangely let Judas' disposition fade into the background, faintly implying that it is 'ambiguous' in some sense. ${ }^{9}$ Thus, Louis Painchaud, who in 2008 argued that this gospel clearly demonstrates why and how Judas surpasses all the other apostles in iniquity, now argues that 'the Gospel of Judas is not at heart intended to praise or blame its titular disciple, nor is it meant to argue for his condemnation or rehabilitation'. ${ }^{10}$ This is also true of recent studies that imply a degree of positivity to Judas; Philippa Townsend underlines both the ambivalence of Judas' character and its possible dissociation from his actions, and Lance Jenott, in his recent book on the gospel, suggests 'shifting the focus of discussion away from

243-88, esp. 263-4. See also Painchaud, 'Polemical Aspects', 184-5: 'through his action Judas becomes simultaneously the initiator and the "archon" of the sacrificial Christianity opposed in our text'. See further J. D. Turner, 'The Place of the Gospel of Judas in Sethian Tradition', The Gospel of Judas in Context, 187-237: 'As the Gospel of Judas now stands, it constitutes a vicious polemic against the sacrificial theology of the so-called apostolic churches at the turn to the third century' (228).

9 This 'ambiguity', to be sure, was present right from the start, especially in the 'evil Judas' camp. Many studies seemed to oscillate back and forth between an evil and pitiable Judas. See, for instance, DeConick, who argued that 'Judas is Ialdabaoth, King of the Archons ... the thirteenth demon, Ialdabaoth himself, who plans Jesus' destruction' ('The Mystery', 254), only to end with the anticlimax that 'Judas emerges from the contours of this gospel as the embodiment of human corruption and human tragedy, as a man who wishes to know God, but a man who cannot finally embrace the Gnostic mysteries' (264). See also Painchaud, who noted that Judas is a demon that 'surpasses all the other apostles in iniquity' ('Polemical Aspects', 178), only to conclude by saying that this 'demonized figure' is 'more the victim of astral fatality than moved by his own free will' (184). In both cases, one cannot help but wonder whether the gospel's author intended to portray Judas as someone to be abhorred and feared (as the demonic ruler of the cosmos) or as someone to be pitied or derided (as an unfortunate and limited individual who is unable, but not unwilling, to reach salvation). If the latter is intended, Elaine Pagels rightly stresses that such a reading places Jesus in the unprecedented position of someone who 'ironically - and quite maliciously - taunts a doomed and hopeless man' (E. H. Pagels, 'Baptism in the Gospel of Judas: A Preliminary Inquiry', The Codex Judas Papers, 353-66, at 363).

10 Painchaud, 'Polemical Aspects', 178 and 'The Dispositio of the Gospel of Judas', ZAC 17 (2013): 268-90, at 289. 
the character of Judas Iscariot and toward ... the immoral character of Jesus' twelve disciples' ${ }^{11}$

I am afraid, however, that that would not do. The valuation of both Judas and his actions are crucial in a gospel that is named after him: he is the main protagonist (the other disciples are not even mentioned by name, and they only speak as a group), he is the one who receives the gnostic revelation, and it is his actions that bring the gospel to a close. Therefore, any interpretation of any aspect of the Gospel of Judas which tries to lay aside Judas is quite dubious. The aforementioned publication by Painchaud is a case in point: while it is clear that he believes Judas to be an evil character in his gospel, Painchaud's own interpretations of the overall structure of the gospel - otherwise quite convincing and sound - are undermined once he lets this issue fall into the background. Painchaud argues that the Gospel of Judas

is always organized in antithetical pairs - the god of the disciples and the Father of Jesus, the holy generation and the other generations, Judas and the other disciples. The decision to use a bipartite form and to present the material in antithetical pairs is perfectly coherent with the goal of the work, namely to lead the reader to make a choice between two opposed modes of behaviour. ${ }^{12}$

One can hardly agree more, but this bipartite division clearly puts Judas on the good side, together with the father of Jesus and the holy generation. And since

11 P. Townsend, 'Sacrifice and Race in the Gospel of Judas', Judasevangelium und Codex Tchacos (ed. E. E. Popkes and G. Wurst; Tübingen: Mohr Siebeck, 2012) 149-72, at 168-9; L. Jenott, The Gospel of Judas: Coptic Text, Translation, and Historical Interpretation of 'The Betrayer's Gospel' (Tübingen: Mohr Siebeck, 2011) 2. A more convincing presentation of an 'ambiguous' Judas has been brought forward, if abruptly, by Bas Van Os. Os argues that 'Judas stands for Gnostic Christians, but only for those who participate in the sacrifices of mainstream Christians', although they know (or should know) that sacrifice is wrong since, like Judas in this gospel, they received the true revelation (B. van Os, 'From the True Israel to True Christianity', Annali di storia dell'esegesi 27 (2010) 61-7, at 67. See also B. van Os, 'Stop Sacrificing! The Metaphor of Sacrifice in the Gospel of Judas', The Codex Judas Papers, 367-86). While this suggestion certainly has merit, I find it hard to corroborate it in the text since throughout Judas is consistently portrayed as uninterested and uninvolved in the other disciples' rituals. For instance, it is at least implied that he does not take part in the Eucharist that opens the gospel, as he (alone) knows that Jesus does not come from the God of Israel (35.14-20). While the other disciples are tainted by the dreams (and prophecies) involving obnoxious rituals (38.2-40.26), Judas dreams of (and wishes to attain) the peaceful house of the holy (44.15-45.24), in which no ritual - sacrificial or otherwise - appears to be taking place. In both cases, he is explicitly contrasted with the others (35.9: 'except Judas Iscariot'; 35.23-4: 'step away from the others'; 44.15-16: 'Master, as you have listened to them, now also listen to me ... I saw the twelve disciples stoning me').

12 Painchaud, 'The Dispositio', 288. 
Painchaud himself also stresses that 'this stark work has no place for a tertium quid', ${ }^{13}$ the reader would have no other option than to choose Judas. ${ }^{14}$

\section{The Death of Jesus in the Gospel of Judas}

I would therefore argue that the question regarding Judas' character and actions should not be ignored or allowed to fade into the background. Instead, I suggest reformulating it by addressing the most important event in this gospel. The Gospel of Judas culminates in the betrayal and the implied crucifixion and death of Jesus: what is the meaning of this event for the author of the gospel? If we now go back to both the positive and the negative understandings of Judas that have been suggested, we will immediately see that the betrayal and its outcome are a recurrent weakness in each and every one of them. The early interpreters of a positive Judas understood Jesus' crucifixion mostly in terms of freeing the gnostic soul from the body. Thus, Judas' 'sacrifice' of Jesus helps the latter to be freed from the body and to return to his heavenly abode. ${ }^{15}$ A more nuanced version of such an understanding, brought forward by Elaine Pagels and Karen King, is that "when Jesus tells Judas to "sacrifice the human being who bears me," he is asking Judas to help him demonstrate to his followers how, when they step beyond the limits of earthly existence, they, like Jesus, may step into the infinite - into God. ${ }^{16}$ However, both suggestions fail to convince. Jesus is already quite free in this gospel and is hardly in any need of Judas' help. ${ }^{17}$ And, on the whole, the gospel's valuation of sacrifice is conspicuously negative; ${ }^{18}$ if the very sacrifice of Jesus is to be understood as inherently different from all

13 Painchaud, 'The Dispositio', 290.

14 This is even more so since Painchaud convincingly demonstrates that the revelation Judas receives is not a later redaction but belongs to the 'original stage of composition of the work' and 'its absence would profoundly disturb the work's underlying structure' ('The Dispositio', 288-9). However, that being so, we are left with no way around the fact that Judas as the recipient of divine revelation is integral to this writing, and thus the gospel's audience, who receive the divine revelation through Judas's book, would inadvertently find themselves in his camp rather than in that of the ignorant disciples.

15 E.g. B. D. Ehrman, The Lost Gospel of Judas Iscariot: A New Look at Betrayer and Betrayed (Oxford: Oxford University Press, 2006) 65 and 99. Cf. also J. M. Robinson, 'The Sources of the Gospel of Judas', Gospel of Judas in Context, 59-67, esp. 66-7.

16 E. H. Pagels and K. L. King, Reading Judas: The Gospel of Judas and the Shaping of Christianity (New York: Viking, 2007) 75.

17 As argued, for instance, by S. Emmel, 'The Presuppositions and the Purpose of the Gospel of Judas', Gospel of Judas in Context, 33-9, at 38; and G. S. Robinson, 'The Relationship of the Gospel of Judas to the New Testament and to Sethianism', Journal of Coptic Studies 10 (2008) 63-98, at 68.

18 See, for instance, Os, 'Stop Sacrificing!'; and E. Thomassen, 'Is Judas Really the Hero of the Gospel of Judas?', Gospel of Judas in Context, 157-70, esp. 165-8. 
the other sacrifices in this gospel - as has indeed been suggested recently ${ }^{19}$ - we should expect some indication of that, faint though it might be, in the text.

But what about the evil Judas? What is the meaning of Jesus' death according to this understanding? Admittedly, by arguing that the disciples and Judas are on an equal footing and only differing in their degree of iniquity, these interpreters stand on firmer ground regarding the gospel's view on sacrifice. All sacrifice is evil, and the sacrifice of Jesus is the worst. But why is it the worst? It must be noted that within the evil Judas interpretation, the betrayal, crucifixion and death of Jesus are ultimately meaningless and pointless in themselves. It is clear that Jesus (or his holy generation) cannot be harmed by that. And actually, the argument of these 'evil Judas' interpreters is not that the archons tried to harm Jesus in any way, and thus Judas' actions are evil in themselves. The argument, propounded by April DeConick and Louis Painchaud among others, is rather that the crucifixion initiated sacrificial theology and thus instigated the utterly wrong cult and belief of proto-orthodox Christianity regarding the death of Christ (which, it should be underlined again, is ultimately meaningless in itself, from a gnostic standpoint). ${ }^{20}$ My sense is that such an interpretation could be credible if, and only if, it can be shown from the text that the sacrificial understanding of Jesus' death was a well-planned conspiracy contrived by Saklas and his archons in order to counteract the gnostic salvation brought by Jesus. That is, one should be able to demonstrate that the evil god, upon witnessing that Jesus was bringing a message of salvation from the true god, devised a wellcrafted deception in collaboration with Judas to counteract this salvation by effecting the idea that Jesus is his son and messenger, and that Jesus' sacrifice will bring salvation to humanity. However, tempting as this understanding can be, I fail to see any corroboration for such a remarkable interpretation within the text. Not only is there an absence of any well-planned craft going on, it is fairly clear that both the disciples and - more importantly - that 'thirteenth demon' Judas are completely at a loss as to what is happening. ${ }^{21}$ The disciples beg Jesus to save

19 See Townsend, 'Sacrifice and Race', 167 and Jenott, The Gospel of Judas, 11.

20 For Judas' betrayal as initiating sacrificial theology, see n. 8 above. For the resulting evaluation of the crucifixion of Jesus as meaningless in this gospel, see, for instance, Emmel, 'The Presuppositions and Purpose', 37: 'Does Jesus' death make any difference at all in the view of the author of this gospel?'; G. S. Robinson, 'An Update on the Gospel of Judas (after additional fragments resurfaced)', ZNW 102 (2011) 110-29, at 118: 'In term of salvation, Judas is simply irrelevant'; Turner, 'The Place of the Gospel of Judas', 221: 'His act of handing over Jesus accomplishes nothing soteriologically significant.'

21 This confusion among the archons and Jesus' enemies is actually stressed by DeConick, despite her understanding of the overall theme of the gospel, when she compares it with the Nag Hammadi Second Treatise of the Great Seth: DeConick, 'The Mystery', 258-9. The only one who appears to have a well-organised plan in this gospel is Jesus himself, but the initiation of sacrificial theology can hardly be ascribed to him according to this interpretation. See also the discussion below, pp. 117-19. 
them (42.4-5), and Judas objects to the idea that his seed is under the control of the archons (46.6-7). He reflects on things exalted (35.22-3), and actually asks (and receives) a reward from Jesus for what he would do (46.16-25). Thus, while the deception of sacrificial theology may lie in the background of this gospel as a pious gnostic afterthought, it does not seem to dominate the events as they occur in the gospel itself.

\section{Salvific Dissolution}

So what is the meaning of Jesus' crucifixion and death in the Gospel of Judas? These events must carry an important and crucial meaning as the gospel is constructed into a well-crafted crescendo that culminates in Jesus' betrayal. Let us return to Irenaeus. What exactly does he say about the Gospel of Judas? Is there something in our gospel that goes against Irenaeus' testimony? Note that Irenaeus knows nothing of Judas being a close or intimate collaborator of Jesus, of Judas freeing Jesus from his body, of Judas being saved, or of sacrificial theology. Irenaeus argues only that in this gospel it is Judas alone who had true knowledge over against the other disciples, and that he accomplished 'the mystery of the betrayal' (proditionis mysterium). Both statements are corroborated in our gospel: Jesus invites Judas to 'step away from the others and I shall tell you the mysteries of the kingdom' (35.23-5; see also 47.1); Judas receives a superior vision of the heavenly place that is reserved for the holy (45.14-20); and, of course, Judas accomplishes the betrayal at the end of the gospel (58.24-6). So, perhaps - just perhaps - Irenaeus was also right as far as the meaning of the betrayal is concerned? Irenaeus argued that the crucifixion of Jesus had 'thrown into confusion' or 'dissolved' (dissoluta) all things, both heavenly and earthly. That is, it caused a turbulence in the archontic world that, we may presume, let the Gnostics (and perhaps the rest of humanity as well) see through the lie of Saklas' world and into the gnostic truth. In the Gospel of Mary we find a very similar formulation intimately related to the salvific work of Christ on earth, when the soul counters the gnostic archons by saying: 'I have recognised that everything is being dissolved, both the earthly and the heavenly (things). ${ }^{22}$ While the Gospel of Mary does not specifically mention the crucifixion in this context, we find the dissolution and crucifixion inextricably connected in the Second Treatise of the Great Seth. Here, the crucifixion - even though it is done by the evil archons in their confused attempt to destroy Jesus - has a reverse effect (58.13-59.14):

22 This parallel has already been suggested by J. van Oort, 'Irenaeus's knowledge of the Gospel of Judas: Real or False? An Analysis of the Evidence in Context', HTS Teologiese Studies / Theological Studies 69 (2013) 1-8, at 5 n. 20. 


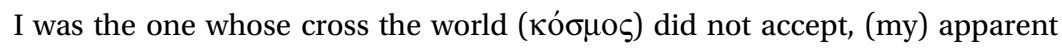

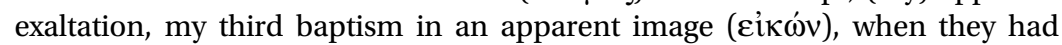
fled from the fire of the seven authorities ( $\dot{\xi} \xi o v \sigma i \alpha)$. And the sun of the powers of the archons ( $\alpha \rho \chi \omega v)$ set, darkness overtook them, and the world

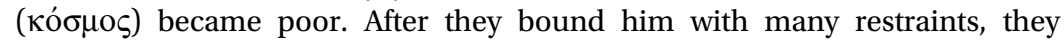
nailed him to the cross, and they fastened him with four nails of bronze. The veil of his temple he tore with his hands. There was a trembling that overcame

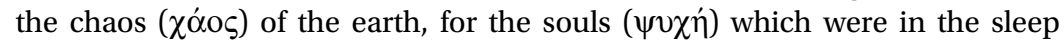
below were released, and they were resurrected. They walked about boldly, having laid aside jealousy of ignorance and unlearnedness beside the dead tombs, having put on the new man, having come to know that blessed and perfect one of the eternal and incomprehensible Father and of the boundless light, which I am. When I came to my own and joined them with myself, there was no need $(\chi \rho \varepsilon i \alpha)$ for many words, for ( $\gamma \alpha \dot{\alpha} \rho)$ our thought ( $\varepsilon^{\prime} v v o 1 \alpha$ ) was with their thought (

And while Judas' role in this salvific dissolution is not mentioned by the author of the Second Treatise of the Great Seth, the Nag Hammadi Concept of Our Great Power does not fail to note his role. Moreover, clearly echoing Jesus' proclamation in the Gospel of Judas on how Judas's 'wrath has been kindled' (пекбшкт аqмоү?, 56.22), the author of the Concept of Our Great Power stresses how fire seized

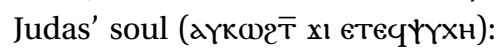

Then ( $\tau$ ó $\tau \varepsilon$ ) a great turmoil arose; the archons roused their wrath against him and wished to deliver him to the ruler of Hades. Then ( $\tau$ ó $\tau \varepsilon)$ they came to know one of his followers; a fire had seized his soul ( $\psi v \chi \eta \dot{)})$. He handed over ( $\pi \alpha \rho \alpha \delta$ ióv $\alpha \mathrm{l})$ him without anyone's knowledge. They acted and seized him; they themselves brought their judgement upon themselves. And they handed over ( $\pi \alpha \rho \alpha \delta 1 \delta$ óv $\alpha$ ) $)$ him (i.e. Christ) to the ruler of Hades but gave him (i.e. Judas) to Sasabek and Berot. He (i.e. Christ) had prepared

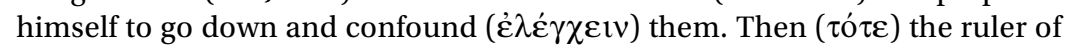
Hades took him, but the manner ( $\tau \rho$ ó $\pi$ o $\zeta)$ of his flesh ( $\sigma \alpha \dot{\rho} \rho \xi$ ) he could not hold, to show it to the archons. But ( $\alpha \lambda \lambda \dot{\alpha})$ he kept repeating: 'Who is this? What is he? His word ( $\lambda$ ó $\gamma \circ \varsigma$ ) has annulled the law (vómos) of the aeon ...' The archons inquired into what has taken place. They did not know that this was the sign ( $\sigma \eta \mu \varepsilon i o v)$ of their destruction and was the change of the aeon. The sun set in the daytime; they day was darkened. The demons ( $\delta \alpha \mu$ óviov) shuddered. And after these things he will appear ascending, and the sign ( $\sigma \eta \mu \varepsilon \hat{i o v}$ ) of the aeon will come to appear, and the aeons will melt away. And blessed ( $\mu \alpha x \alpha$ ó $\varsigma_{)}$) will be those who will understand (voeiv) ... And they will be revealed and be blessed because they will have understood (vocîv) the truth. ${ }^{24}$

23 Translation from B. Pearson, 'Second Treatise of The Great Seth', The Coptic Gnostic Library A Complete Edition of the Nag Hammadi Codices (ed. J. M. Robinson; Brill Online, 2014).

24 The Concept of Our Great Power, 41.13-42.29; translation and emendations according to F. E. Williams, Mental Perception: A Commentary on NHC VI.4 The Concept of Our Great Power (Leiden: Brill, 2001) 8-11, with slight revisions: I have consistently translated $\pi \alpha \rho \alpha \delta 1 \delta$ óv $\alpha 1$ 
Considering these parallels, then, it may not be far-fetched to suggest that Irenaeus was right regarding the effect of Judas' betrayal as well, and the crucifixion of Jesus in the Gospel of Judas was salvific (according to the Gnostics) since it started a process of dissolution that gave away the lie of the archontic world and allowed the salvation of the holy generation. The fragmentary state of Codex Tchacos prevents a definite conclusion, but it is important to note that the Gospel of Judas shares much of its imagery with the Second Treatise of the Great Seth and The Concept of Our Great Power. ${ }^{25}$ Moreover, there is nothing in the gospel that contradicts such an understanding, and, most importantly, the main motif of the work even seems to recommend it; the stars, as a part of the archontic world, are evil, but at the same time they 'bring everything to completion' (40.17-19) and thus initiate an apocalyptic salvation. While the holy generation will ultimately rest in the place where neither the sun nor the moon rule (45.20-1), this is clearly not the present situation. Each disciple has a star (42.7-8), including Judas. The disciples' stars lead them to their atrocious activity (38.1-40.18), thus drawing near the dissolution, perhaps even in the sense of Mitzvah HaBaa BeAvera, or salvation through sin. ${ }^{26}$ But the star of Judas instructs him to betray Jesus (56.23), and leads the way after Jesus when he enters into the cloud (57.15-20), thus prefiguring his betrayal and crucifixion which will trigger the salvific dissolution. Both the disciples and Judas have a part in initiating the salvific dissolution, then, with the important distinction that the disciples do this inadvertently and unknowingly, while Judas has gnōsis.

as 'handed over' (Williams uses 'betrayed' for Judas and 'delivered' for the archons) and have preferred to leave aeon(s) untranslated throughout. Note how The Concept of Our Great Power lays all the blame on the archons, not on Judas, who ends up being a victim himself. For discussion of this scene from the The Concept of Our Great Power and its many parallels to the Second Treatise of the Great Seth, as well as the identity of the demons Sasabek and Berot, see Williams, Mental Perception, 114-33. Yet another parallel is provided by the Paraphrase of Shem 39.28-40.1, in which Nature, the collaborator of the Hebrew Bible god, tries to destroy Jesus but only succeeds in crucifying Soldas and initiating her own demise. See the discussion in M. Roberge, The Paraphrase of Shem (NH VII, 1): Introduction, Translation, and Commentary (Leiden: Brill, 2010) 17.

25 Scholars have noted the parallels between the Gospel of Judas, The Second Treatise of the Great Seth and The Concept of our Great Power, if not specifically accentuating the salvific dissolution caused by Jesus' crucifixion. See, for instance, DeConick, 'The Mystery,' 257-62; F. Williams, 'The Gospel of Judas: Its Polemic, its Exegesis, and its Place in Church History', Vigiliae Christianae 62 (2008) 371-403, at 375-6; J. M. Robinson, 'The Sources of the Gospel of Judas', 67.

26 For this concept, see G. Scholem, The Messianic Idea in Judaism (New York: Schocken Books, 1972) 78-141. 


\section{The Mystery of the Betrayal}

But could the issue thus be decided? Do we have an utterly positive Judas who knowingly brings salvation through his betrayal? My answer is no ... and yes. While it is obvious that Judas' actions are good and they should necessarily interact with his character, and while Judas does receive gnōsis from Jesus, he is evidently not considered as a gnostic disciple in this gospel: it is clearly stated that he will never belong to the holy generation (45.11-19 and 46.25-47.1). But how could that be explained? My suggestion is that this gospel is actually the explanation of this very paradox, but that it is perhaps not entirely clear and - due to the state of the manuscript - is quite a fragmentary explanation. It may be that this work was composed by a gnostic who inquired into a question which the writers of the New Testament and other early proto-orthodox Christians rarely tackled: assuming that Jesus' crucifixion was crucial to salvation, how should Judas be evaluated?

\subsection{The New Testament and Later Christian Sources}

The earliest sources on Jesus' crucifixion are notoriously silent regarding the role and motive of Judas in this event. Paul apparently knows nothing of Judas or of a betrayal. To be sure, he is aware that Jesus was 'handed over' to be crucified, but, quite logically from the perspective of a person who believed in the salvation of the cross, when he does ascribe this 'handing over' to

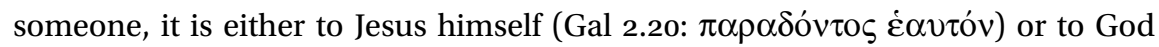

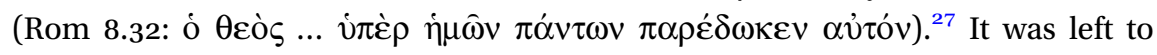
later sources to set the record straight. While Mark still preserved some ambiguity in Jesus' famous prophecy that 'the Son of Man goes as it is written of him, but woe to that one by whom the Son of Man is betrayed! It would have been better for that one not to have been born' (Mark 14.21 NRSV) - an ambiguity that was to be taken over by Luke (22.22) and Matthew (26.24) - later sources almost uniformly and unequivocally stressed the malevolence of Judas. ${ }^{28}$ This is

27 It is quite clear from the context that the verb $\pi \alpha \rho \alpha \delta i \delta \omega \mu$ does not carry the negative meaning of 'betrayal' for Paul. For discussion of the range of meanings of this word in Greek, including Paul's usage, see W. Klassen, Judas: Betrayer or Friend of Jesus? (Minneapolis: Fortress, 1996) 47-61.

28 This is the rather depressing conclusion of many studies on the figure of Judas in the ancient sources. See, for instance, A. W. Zwiep, Judas and the Choice of Matthias: A Study on the Context and Concern of Acts 1:15-26 (Tübingen: Mohr Siebeck, 2004) 8: 'Historically, the most dominant and traditional type of Judas depicts him as an embodiment of wickedness, the incarnation of evil.' See also K. Paffenroth, Judas: Images of the Lost Disciple (Louisville: Westminster John Knox, 2001) 17-58, and the collection of sources provided by M. Meyer, Judas: The Definitive Collection of Gospels and Legends about the Infamous Apostle of Jesus (San Francisco: HarperOne, 2007), who notes that 'from the second century on, the figure of Judas Iscariot has been increasingly demonized in Christian literature' (p. 109). 
evident in Luke-Acts and Matthew, who make sure Judas will not go unpunished and inform us of his death either by suicide (Matt 27.5) or by a gruesome 'accident' (Acts 1.18). As Arie Zwiep notes, since there are 'no uninterpreted versions of Judas' death', both Luke and Matthew as well as later Christian tradition stressed the terrible end of Judas in conformity with Jewish and Greco-Roman literary conventions of theodicy: 'a wicked man will die a wicked death'. ${ }^{29}$ And even though the Gospel of John begs to differ here and does not mention Judas' horrific end, the author of this gospel still employs the utmost Greco-Roman character typing in order to accentuate Judas' guilt. ${ }^{30}$ Later sources would only increase Judas' malevolence to absurd proportions, by looking either to the past, at the wicked and demon-ridden child he was, or to his prolonged suffering and appalling aftermath. ${ }^{31}$

\subsection{The Gospel of Judas}

Unbounded by the New Testament authors' portrayal of an evil Judas, being at a safe distance from the historical event, and also having a very different understanding of death in general - and the (apparent) death of Jesus in particular (cf. 56.19-20) - the author of the Gospel of Judas took a different route to try and explain Judas' character and motives. This author reasoned that Judas could not be that bad as he contributed to salvation and he also opposed the proto-orthodox. While my enemy's enemy is not always necessarily my friend, he may have some good points. ${ }^{32}$ Further, our author reasoned, in order to initiate salvation, Judas had to know something about the gnostic world (as opposed to the proto-orthodox), and this knowledge could have been provided by no one

29 Zwiep, Judas, 123 and 71.

30 See W. M. Wright, 'Greco-Roman Character Typing and the Presentation of Judas in the Fourth Gospel', CBQ 71 (2009) 544-59: 'Through the use of Greco-Roman character typing, John articulates a strongly negative presentation of Judas as a virtual embodiment of evil and vice, the unfaithful disciple who hands his master over to his death' (p. 559). Indeed, it may be that John was unaware of any tradition regarding Judas' death. For discussion, see Zwiep, Judas, 42-5.

31 For Judas as an evil child, see the discussion of the Arabic Infancy Gospel in Paffenroth, Judas, 24-6. For Judas' (unbearably) detailed gruesome aftermath according to Papias, see, for instance, C. B. Zeichmann, 'Papias as Rhetorician: Ekphrasis in the Bishop's Account of Judas' Death', NTS 56 (2010) 427-9.

32 Anders Klostergaard Petersen appears to be suggesting a characterisation of Judas along these lines when he notes that 'if one - like the author behind the Gospel - understands mainstream forms of Christianity to be false, their negative ascription of value to Judas can be used as a positive witness that he possesses special knowledge reflecting the true god.' However, he also stresses that Judas 'continues to be a negative figure, because he has delivered Jesus, a fact which the Gospel of Judas also accords negative value' (A. Klostergaard Petersen, 'The Gospel of Judas: A Scriptural Amplification or a Canonical Encroachment?', Judasevangelium und Codex Tchacos, 253-90, at 289-90 and 282). 
other than Jesus himself. Such a knowledge may have caused Judas to entertain some hopes for salvation, but since our author did not find any rationale or precedent for such a claim they probably refrained from making this further step. The author did reason, however, that Judas was entitled for something in exchange for his service, and he received it. Such a scenario appears to me to be the only one that provides a sufficient explanation for the following, otherwise opaque, interchange between Jesus and Judas (46.12-23):

'... you will grieve much when you see the kingdom and all its generation.' When Judas heard this he said to him, 'What is the advantage that I have received? For you have set me apart from that generation.' Jesus answered and said, 'You will become the thirteenth, and you will be cursed by the other generations, and you will come to rule over them ... ${ }^{33}$

The Coptic word zoyo which has been translated as 'advantage' could just as easily have been translated as 'profit', ${ }^{34}$ stressing further that Judas believed he should be rewarded by Jesus for what he would do (and thus could hardly be the extremely evil Judas that tried to block salvation) and that Jesus, while agreeing that Judas should be rewarded, would only allow him a second prize (and thus can hardly have considered Judas his closest and most trusted collaborator). ${ }^{35}$ This is probably the conclusion that our gnostic author was able to devise: while Judas was helpful in bringing about salvation, and knew what he was doing, he was no gnostic. The other disciples, cattle no less than the cattle they lead astray on the altar (39.25-8), were not even worthy of consideration and now ignorantly blame everything on Judas. The author of the gospel added a finishing touch changing Judas' aftermath: since he was not evil, gruesome death did not seem apt. On the contrary, he could even be imagined as the first 'internal'

33 Kasser et al., Gospel of Judas: Critical Edition, 211.

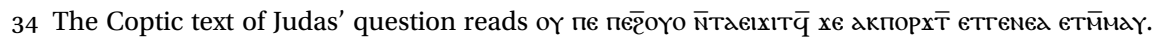

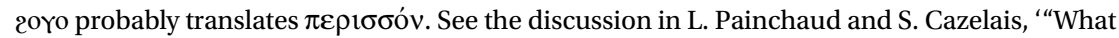
is the Advantage?" (Gos. Jud. 46.16): Text, Context, Intertext', The Codex Judas Papers, 437-52. I have provided the translation of the critical edition, but preferred 'from that generation' instead of 'for that generation'. Quite strikingly, it is the very same word Jesus uses to describe the difference between Judas and the other disciples' actions when he says: 'you will do more

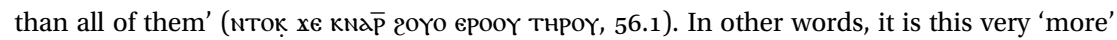
that Judas does regarding which he requests his reward, and thus it should not be understood as meaning simply 'more evil' or 'worse'.

35 Further support for this reading is provided if we read the title of the work пеүaṛ as 'the good news for Judas', as suggested by Marvin Meyer: 'the common pseudonymous attribution that a gospel is the good news "according to" (Катd or пкגTa) a given disciple or apostle is not provided here. Rather, this is the good news of Judas, perhaps about Judas or even for Judas' (M. Meyer, 'Interpreting Judas: Ten Passages in the Gospel of Judas', The Gospel of Judas in Context, 41-55, at 42). 
martyr, as the first to feel the violence of the proto-orthodox church. ${ }^{36}$ Thus he did not burst open by falling in his own field as in Acts, much less did he hang himself as in Matthew, but was rather stoned by the other disciples (44.26-45.1), only to eventually become their ruler. ${ }^{37}$

Where, then, does that leave us? It leaves us with a gospel that clearly corroborates its contemporary description by Irenaeus while being the thought experiment of a gnostic who believed in the salvific dissolution brought through the crucifixion of Christ, as portrayed in the Second Treatise of the Great Seth and directly aligned with Judas' action in the Concept of our Great Power. In the former, Judas is not mentioned, and the latter only enigmatically refers to his role and proceeds to lay all the blame on the archons. Consequently, such lacunae may have been exactly what motivated our author to inquire after Judas' motives, role and aftermath, and to produce a document like the Gospel of Judas. It was thus not a parody - and that solves the problem that we have no parallel for such a parodic writing - and Judas was not evil - which in turn solves the problem that we have no example of a gospel ascribed to an evil character. ${ }^{38}$ The writer of this gospel tried to tackle a question that, as we have seen, very few other early Christians had dared to address directly. While Paul could only ascribe Jesus' 'handing over' to Jesus himself (Gal 2.20) or to God (Rom 8.32), and Mark's gospel still faintly stresses the ambiguity of Judas and his actions (Mark 14.21), later protoorthodox Christian tradition almost unequivocally accentuated Judas' iniquity and his dismal aftermath to preposterous dimensions, as though exaggeration or shouting the loudest might successfully banish any intimidating ambiguity. ${ }^{39}$

36 As Klostergaard Petersen notes, the author of the Gospel of Judas is aware of Luke-Acts, since he knows about the tradition of the replacement of Judas by Matthias (Klostergaard Petersen, 'Gospel of Judas', 258). Awareness of Matthew's gospel (and thus the tradition regarding Judas hanging himself) is also possible: See S. J. Gathercole, 'Matthean or Lukan Priority? The Use of the NT Gospels in the Gospel of Judas', Judasevangelium und Codex Tchacos, 291-302. It may not be a coincidence that the Second Treatise of the Great Seth, which parallels the Gospel of Judas in so many ways, also alludes to the persecution of gnostics by the proto-orthodox church: 'we were hated and persecuted, not only (by) those who are ignorant, but by those also who think that they are advancing the name of Christ since they are vain in ignorance' (59.22-7).

37 Klostergaard Petersen notes two additional tweaks that the author of the Gospel of Judas applies to the New Testament gospels' traditions, both of which would provide further support for my interpretation. In the betrayal scene of the Gospel of Judas (58.19-24) it is, contrary to the unequivocal testimony of the Synoptics, the scribes who approach Judas to hand Jesus over to them, and not vice versa. Judas is just tacitly acknowledged to have 'answered them as they wished' in what appears to be a clever recast of Peter's denial of Jesus, except that Judas does not deny that he is Jesus' disciple (Klostergaard Petersen, 'Gospel of Judas', 259).

38 These problems have been stressed by Pagels, 'Baptism in the Gospel of Judas', esp. 353-7.

39 It apparently took almost 2,00o years for an orthodox (or a quasi-orthodox) literary solution to be formed by the Greek author Nikos Kazantzakis (1883-1957). In his novel The Last 
The author of the Gospel of Judas, on the other hand, apparently had the integrity to acknowledge directly that without Judas' betrayal there would have been no salvation and to inquire how this was possible without recasting the Judas affair as 'a divine trick at the unfortunate cost of a human individual'. ${ }^{40}$ The solution our author provided to this 'mystery of the betrayal' may be judged to be either a modest success or a glorious failure. But at least they tried.

Temptation of Christ, published in 1951, he has Judas approach Jesus with the following words: 'You broke my heart ... You took me in your arms - do you remember? - and begged, "Betray me, betray me. I must be crucified and resurrected so that we can save the world!"' (N. Kazantzakis, The Last Temptation of Christ, trans. P. A. Bien (New York: Simon and Schuster, 1960) 491-2). In the unforgettable closing scene of Martin Scorsese's film adaptation of the novel (Universal City, CA: Universal Pictures, 1988) these words were spoken by Harvey Keitel in his role as Judas Iscariot.

40 This is exactly the question that Zwiep brings to the ancient sources from a modern theological viewpoint, but which they are unable (or unwilling) to answer: Zwiep, Judas, 8-9. 